\title{
COMPARATIVE EVALUATION OF EFFICACY OF MIDAZOLAM IN DIFFERENT DOSES AS AN INDUCTION AGENT
}

Pachaimuthu Elango1, Gurusamy Sivakumar², Anbu Srinivasan³, Ugrapandian Vijaya Shanmugam ${ }^{4}$

1Professor, Department of Anaesthesiology, KAP Viswanatham Government Medical College, MGMGH, Tiruchirapalli.

2Professor, Department of Anaesthesiology, KAP Viswanatham Government Medical College, MGMGH, Tiruchirapalli.

${ }_{3}^{3}$ Associate Professor, Department of Orthopaedics, KAP Viswanatham Government Medical College, MGMGH, Tiruchirapalli.

4Professor, Department of Ophthalmology, KAP Viswanatham Government Medical College, MGMGH, Tiruchirapalli.

\section{BACKGROUND}

ABSTRACT

Induction involves the transition from an awake conscious state with intact productive reflexes to an unconscious state. Induction is accomplished when there is no response to oral commands and loss of eyelash reflexes. The Induction of general anaesthesia is characterised by rapid loss of consciousness which is an indicator of light surgical plane of anaesthesia. Midazolam is a water soluble short-acting benzodiazepine. Midazolam possesses some of the properties of an ideal intravenous anaesthetic agent and hence has been evaluated as an induction agent for an ideal dosage.

The aim of the study was to find out a minimum effective dose of midazolam by comparing $0.25 \mathrm{mg} / \mathrm{kg}$ and $0.30 \mathrm{mg} / \mathrm{kg}$ body weight as an induction agent in general anaesthesia and study about its responses namely smoothness of induction, haemodynamic changes and respiratory status during induction.

\section{MATERIALS AND METHODS}

In this prospective randomised and double-blind study, sixty cases posted for abdominal surgeries were enrolled. Patients received the study drugs in a randomised manner. Group I patients received midazolam $0.25 \mathrm{mg} / \mathrm{kg}$ while group II patients received midazolam $0.3 \mathrm{mg} / \mathrm{kg}$ for induction of anaesthesia. The observations were analysed using student's test and Chi-square test to compare the data between groups.

\section{RESULTS}

Midazolam can be used as an induction agent in patients undergoing major surgical procedures without any systemic complications.

\section{CONCLUSION}

This study showed that Midazolam in a dose of $0.3 \mathrm{mg} / \mathrm{kg}$ was more ideal to induce clinically acceptable anaesthesia since induction and recovery were smooth and pleasant.

\section{KEYWORDS}

General Anaesthesia, Intravenous Induction, Midazolam.

HOW TO CITE THIS ARTICLE: Elango P, Sivakumar G, Srinivasan A, et al. Comparative evaluation of efficacy of midazolam in different doses as an induction agent J. Evolution Med. Dent. Sci. 2017;6(95):6965-6970, DOI: 10.14260/jemds/2017/1512

\section{BACKGROUND}

The induction of general anaesthesia is characterised by rapid loss of consciousness which is an indicator of a light surgical plane of anaesthesia. During this transition from awareness to unconsciousness, maintenance of a patient's airway with adequate ventilation and preservation of cardiovascular function is important. Estimation of the depth of anaesthesia is an art rather than science. The goal is to provide sufficient depth of anaesthesia for surgery with the least amount of the anaesthetic to minimise the response. The depth is usually estimated by the changes in heart rate and blood pressure to surgical stimulation.

The pharmacological characteristic of benzodiazepines include amnesia, sedation, hypnosis and the production of minimal depression of cardiovascular and respiratory systems.

'Financial or Other Competing Interest': None.

Submission 06-10-2017, Peer Review 08-12-2017,

Acceptance 14-12-2017, Published 23-12-2017.

Corresponding Author:

Dr. Gurusamy Sivakumar

\#5/7, Race Course Road,

Professor's Colony, Trichy-620020.

E-mail: drsivakumar08@yahoo.com

DOI: $10.14260 /$ jemds $/ 2017 / 1512$

\section{(c) $(1)(5)$}

There are separate benzodiazepine and GABA receptors coupled to a common chloride channel and the benzodiazepine receptor acts as a regulatory mechanism for GABA receptors. Midazolam is also thought to inhibit the reuptake of GABA, thereby causing accumulation of GABA. The anxiety and muscle relaxant activity occurs at the mammillary body, brainstem and spinal cord which is mediated through glycine receptors in the spinal cord and brainstem. ${ }^{1}$

Ever since John Silas Lundy introduced the balanced anaesthesia, ${ }^{2}$ the quest for an ideal, short acting, safe and pleasant induction agent is on the whole increasing. General anaesthesia is produced by drugs which depress the functional elements in CNS but doses required to produce surgical anaesthesia are so large that cardiovascular and respiratory depression occurs commonly and the recovery from anaesthesia is delayed for hours or even days.

Only a few drugs are suitable for routine use as anaesthetic agents, which can achieve anaesthesia within few minutes and is rapidly reversible which rule out any long-term biochemical changes as basic for narcosis. But there is a dose relation between potency of a compound and its lipid solubility and it is suggested that anaesthesia results when specific number of molecules occupy crucial hydrophobic sites in the CNS. 
Anaesthetic agents either inhalational or intravenous act by blocking the excitatory synaptic transmission. Some agents act by prolonged synaptic inhibition. An ideal intravenous anaesthetic induction agent should be reliable and pleasantly induce anaesthesia in one arm-brain circulation time.

Midazolam is a water soluble short-acting benzodiazepine. ${ }^{3}$ It can be mixed with any IV fluids and possess some of the properties of an ideal intravenous anaesthetic agent and hence been evaluated as an induction agent for an ideal dosage. 4

Aim of the study was to find a minimum effective dose of midazolam by comparing $0.25 \mathrm{mg} / \mathrm{kg}$ and $0.30 \mathrm{mg} / \mathrm{kg}$ body weight as an induction agent in general anaesthesia and study its responses namely smoothness of induction, haemodynamic changes during induction, respiratory status during induction, other complication such as involuntary muscle movement, hiccup \& laryngospasm, postoperative recovery and sedation. 5,6

\section{MATERIALS AND METHODS}

A double blind, prospective randomised study was done to evaluate the efficacy of intravenous midazolam in various doses as an induction agent in general anaesthesia. This clinical study was conducted in KAP Viswanatham Government Medical College/MGMGH, from July 2002 to July 2003. The hospital ethical committee approved this study and informed consent was obtained from each and every patient. It is postulated that a drop in $3 \mathrm{mmHg}$ of diastolic blood pressure with increased dose is graded as good clinical response with a standard deviation of $4 \mathrm{mmHg}$. The calculated sample size was found to be 26 in each group with an effect size of 0.75 and for a two-sided test of $5 \%$ with a power of $80 \%$. This study was conducted on 60 adult patients of ASA I \& II. Block randomisation technique used to allocate the patients to Group I and Group II. Blocks of varying sizes ranging from 2 - 6 used for block randomisation. The patients were divided into two groups (Group I \& Group II) of 30 each with patients of either sex in the age group of 20 to 60 years with the average weight of 40 to 60 kilograms.

\section{Inclusion Criteria}

In this prospective randomised and double-blind study, sixty cases, of either sex, ASA I \& II criteria and weight range of 40 to $60 \mathrm{~kg}$, posted for various abdominal surgeries were enrolled.

\section{Exclusion Criteria}

Pregnant and lactating patients, patients with cardiovascular, respiratory, hepatic, renal and other systemic illness were excluded from the study. Patients receiving benzodiazepines therapy and addicted to alcohol were also excluded from the study.

\section{Preoperative Evaluation}

In all the patients, history was obtained regarding previous anaesthesia, any significant medical or surgical illness and medication, smoking and alcohol habits. A complete physical examination was done. In all patients, the age, pre-operative bodyweight, heart rate and blood pressure were recorded. The preoperative lab investigations done are urine albumin, sugar,
$\mathrm{Hb}$ percentage, blood urea, blood sugar, serum creatinine, $\mathrm{X}$ ray chest, ECG.

All patients received a standard premedication with injection pentazocine lactate $30 \mathrm{mg}$ and injection glycopyrrolate $0.2 \mathrm{mg}$ intramuscularly 45 minutes prior to the induction of anaesthesia. Patients received the study drugs in a randomised manner, group I patients received midazolam $0.25 \mathrm{mg} / \mathrm{kg}$ while group II patients received midazolam 0.3 $\mathrm{mg} / \mathrm{kg}$ for induction of anaesthesia. The observations were done using multimonitor GENERRA $710 \mathrm{MX}$.

Pre-induction observations included were blood pressure, pulse rate and respiratory rate. The patients are preoxygenated with 5-8 litres of oxygen per minute for 3 minutes. The calculated dose of induction agents was given over a period of 30 seconds and further two minutes were allowed for the drug to take effect. The blood pressure, heart rate, respiratory rate and the presence or absence of apnoea were recorded immediately before and after induction. The induction time and duration of apnoea (defined as absence of spontaneous respiration for 20 seconds of more) and other excitatory efforts (such as involuntary movements, twitching, and tremor), hiccup, cough and pain during injection were noted.

After a period of two minutes, succinylcholine $2 \mathrm{mg} / \mathrm{kg}$ was given and intubation was carried out. Immediately following intubation, the blood pressure and heart rate were recorded. Anaesthesia was maintained with nitrous oxide and oxygen. Controlled ventilation was done and muscle relaxant was obtained with pancuronium bromide. The variables are noted at premedication, post-induction, post-intubation, 3 min., 5 min., 10 min., 15 min., 30 min., 45 min., $60 \mathrm{~min}$. and every 30 minutes thereafter till end of the surgery. On spontaneous respiratory effort from the patient, reversal from anaesthesia was accomplished with Inj. Neostigmine 0.04 $\mathrm{mg} / \mathrm{kg}$ and Inj. Atropine $0.02 \mathrm{mg} / \mathrm{kg}$ and all patients in this study were extubated. Time to alertness following administration of the reversal agent was recorded. Patient's response to commands, spontaneous breathing, vomiting, blood pressure, oxygen saturation, total duration of anaesthesia and the post-operative sedation following extubation were noted.

\section{Statistical Analysis}

The collected data were analysed by using Epi info software version 7.2.2.2 for independent sample t-test. The results are obtained in the form of range, mean and standard deviation. The probability value ' $p$ ' of less than 0.05 was considered statistically significant.

\section{RESULTS}

The study was conducted on a total 60 patients undergoing various operative procedures. The patients were divided into two groups; Group I (n: 30) patients received midazolam 0.25 $\mathrm{mg} / \mathrm{kg}$ and Group II (n: 30) patients received $0.30 \mathrm{mg} / \mathrm{kg}$ for induction of anaesthesia. Out of the total of 60 patients, 23 were ASA I and 7 were ASA II in group I and 24 were ASA I and 6 were ASA II in group II. All the patients were adults ranging from 20 to 60 years and the two groups of patients were broadly comparable in respect to average age, weight, male, and female distribution ( $\mathrm{p}$ value $>0.05$ ). 


\begin{tabular}{|c|c|c|}
\hline Age in Years & Group I (n=30) & Group II (n=30) \\
\hline $20-30$ & 16 & 12 \\
\hline $31-40$ & 10 & 11 \\
\hline $41-50$ & 4 & 4 \\
\hline $51-60$ & 0 & 3 \\
\hline Min-Max & $20-48$ & $23-58$ \\
\hline Mean & 31.40 & 35.80 \\
\hline SD & 9.028 & 10.017 \\
\hline P value & \multicolumn{2}{|c|}{$0.109>0.05 \mathrm{NS}$} \\
\hline \multicolumn{3}{|c|}{ Table 1. Age Incidence } \\
\hline
\end{tabular}

\begin{tabular}{|c|c|c|}
\hline Sex Distribution & Group I (n=30) & Group II (n=30) \\
\hline Male & 22 & 23 \\
\hline Female & 8 & 7 \\
\hline \multicolumn{3}{|c|}{ P value 0.747>0.05 NS } \\
\hline \multicolumn{3}{|c|}{ Table 2. Sex Incidence } \\
\hline
\end{tabular}

\begin{tabular}{|c|c|c|}
\hline $\begin{array}{c}\text { Weight in Kg } \\
\text { (Min-Max) }\end{array}$ & Group I (n=30) & Group II (n=30) \\
\hline $40-60$ & 22 & 23 \\
\hline $42-60$ & 8 & 7 \\
\hline \multicolumn{3}{|c|}{ P value 0.252>0.05 NS } \\
\hline \multicolumn{3}{|c|}{ Table 3. Weight in $\mathbf{~ g ~}$} \\
\hline
\end{tabular}

\begin{tabular}{|c|c|c|}
\hline Induction Time & $\begin{array}{c}\text { Group I } \\
(\mathbf{n = 3 0 )}\end{array}$ & $\begin{array}{c}\text { Group II } \\
(\mathbf{n = 3 0 )}\end{array}$ \\
\hline Mean value in seconds & 113.12 & 108.08 \\
\hline SD & 15.431 & 16.039 \\
\hline \multicolumn{2}{|c|}{ P value 0.263>0.05 NS } \\
\hline \multicolumn{2}{|c|}{ Table 4. Induction Time in Seconds }
\end{tabular}

\begin{tabular}{|c|c|c|}
\hline Recovery Time & Group I (n=30) & Group II (n=30) \\
\hline Mean value in seconds & 377.88 & 430.80 \\
\hline SD & 134.66 & 153.45 \\
\hline \multicolumn{3}{|c|}{ P value 0.249>0.05 NS } \\
\hline \multicolumn{2}{|c|}{ Table 5. Recovery Time in seconds }
\end{tabular}

The mean induction time following midazolam administration in group I was 113.12 seconds with a range of 92 to 141 seconds and in group II it was 108.08 seconds with range of 80 to 132 seconds and the p value was 0.263 . The mean recovery time in group I was 377.88 seconds and group II was 430.88 and the p value was 0.249 .

\begin{tabular}{|c|c|c|}
\hline $\begin{array}{c}\text { Respiratory Rate } \\
\text { (per min.) }\end{array}$ & $\begin{array}{c}\text { Group I } \\
\text { (n=30) }\end{array}$ & $\begin{array}{c}\text { Group II } \\
\text { (n=30) }\end{array}$ \\
\hline Pre-induction Mean value & 15.88 & 16.28 \\
\hline SD & 1.509 & 1.370 \\
\hline \multicolumn{2}{|c|}{ P value 0.331>0.05 NS } \\
\hline \multicolumn{2}{|c|}{ Table 6. Pre-Induction Changes in Respiratory } \\
Rate per Minute
\end{tabular}

\begin{tabular}{|c|c|c|}
\hline $\begin{array}{c}\text { Respiratory Rate } \\
\text { (per min.) }\end{array}$ & $\begin{array}{c}\text { Group I } \\
\text { (n=30) }\end{array}$ & $\begin{array}{c}\text { Group II } \\
\text { (n=30) }\end{array}$ \\
\hline Post-induction Mean value & 13.36 & 12.48 \\
\hline SD & 1.524 & 1.564 \\
\hline \multicolumn{2}{|c|}{ P value 0.051>0.05 NS } \\
\hline \multicolumn{2}{|c|}{ Table 7. Post-Induction Changes in Respiratory } \\
Rate per Minute
\end{tabular}

The respiratory rate in the pre-induction period was 15.88 in group I \& 16.28 in group II. However, following induction, the respiratory rate decreased to $13.36 \& 12.48$ respectively.

\begin{tabular}{|c|c|c|c|c|c|}
\hline \multirow{2}{*}{ Time } & \multicolumn{2}{|c|}{ Group I (n=30) } & \multicolumn{2}{|c|}{ Group II $(n=30)$} & \multirow{2}{*}{$\begin{array}{c}\text { p value }(<0.05 \\
\text { significant })\end{array}$} \\
\hline & HR/minute & SD & HR/minute & SD & \\
\hline Pre-induction & 96.16 & 17.107 & 94.32 & 17.194 & 0.706 \\
\hline Post-induction & 88.88 & 14.175 & 86.16 & 15.721 & 0.524 \\
\hline Post-intubation & 114.16 & 13.972 & 104.12 & 12.788 & 0.011 \\
\hline 3 minutes & 111.00 & 13.351 & 103.28 & 11.212 & 0.032 \\
\hline 5 minutes & 107.56 & 12.114 & 113.04 & 10.097 & 0.158 \\
\hline 10 minutes & 101.40 & 12.107 & 101.00 & 8.456 & 0.089 \\
\hline 15 minutes & 95.80 & 13.061 & 100.20 & 10.440 & 0.195 \\
\hline 30 minutes & 94.84 & 13.108 & 97.96 & 11.639 & 0.037 \\
\hline 45 minutes & 96.12 & 12.451 & 97.48 & 16.282 & 0.074 \\
\hline 60 minutes & 94.48 & 12.221 & 96.24 & 12.521 & 0.617 \\
\hline
\end{tabular}

Heart rate decreased from the baseline value in both groups after induction, but there was no significant difference between the two groups. The heart rate in the pre-induction period was 96.16 which decreased to 88.88 in group I and 94.32 to 86.16 in group II in post-induction period.

\begin{tabular}{|c|c|c|c|c|c|}
\hline \multirow{2}{*}{ Time } & \multicolumn{2}{|c|}{ Group I (n=30) } & \multicolumn{2}{c|}{ Group II (n=30) } & $\begin{array}{c}\text { p value } \\
(<\mathbf{0 . 0 5} \\
\text { Significant) }\end{array}$ \\
\cline { 2 - 6 } & $\begin{array}{c}\text { Systolic Blood } \\
\text { Pressure }\end{array}$ & SD & $\begin{array}{c}\text { Systolic blood } \\
\text { Pressure }\end{array}$ & SD & 0.457 \\
\hline Pre-induction & 121.52 & 21.903 & 125.44 & 14.312 & 0.289 \\
\hline Post-induction & 111.12 & 8.946 & 108.00 & 11.489 & 0.437 \\
\hline Post-intubation & 142.00 & 17.049 & 138.40 & 13.191 & 0.496 \\
\hline 3 minutes & 138.80 & 11.518 & 136.40 & 11.328 & 0.804 \\
\hline 5 minutes & 134.00 & 11.314 & 131.20 & 11.698 & 0.742 \\
\hline 10 minutes & 130.28 & 13.050 & 131.44 & 10.134 & 0.025 \\
\hline 15 minutes & 133.84 & 11.298 & 130.88 & 9.065 & 0.508 \\
\hline 30 minutes & 125.52 & 11.170 & 127.44 & 11.128 & 0.357 \\
\hline 45 minutes & 124.64 & 10.128 & 127.44 & 11.649 & 0.562 \\
\hline 60 minutes & 125.32 & 10.111 & 127.12 & & \\
\hline
\end{tabular}




\begin{tabular}{|c|c|c|c|c|c|}
\hline \multirow[b]{2}{*}{ Time } & \multicolumn{2}{|c|}{ Group I (n=30) } & \multicolumn{2}{|c|}{ Group II (n=30) } & \multirow[b]{2}{*}{$\begin{array}{c}\text { p value } \\
(<0.05 \\
\text { Significant })\end{array}$} \\
\hline & \begin{tabular}{|c|} 
Diastolic \\
Blood \\
Pressure
\end{tabular} & SD & $\begin{array}{l}\text { Diastolic } \\
\text { Blood } \\
\text { Pressure }\end{array}$ & SD & \\
\hline \begin{tabular}{|c|} 
Pre- \\
induction \\
\end{tabular} & 82.28 & 8.444 & 85.60 & 10.954 & 0.236 \\
\hline $\begin{array}{c}\text { Post- } \\
\text { induction }\end{array}$ & 73.80 & 6.856 & 72.08 & 7.474 & 0.401 \\
\hline $\begin{array}{c}\text { Post- } \\
\text { intubation }\end{array}$ & 94.68 & 1.671 & 92.40 & 9.110 & 0.469 \\
\hline 3 minutes & 91.72 & 8.829 & 91.20 & 9.274 & 0.840 \\
\hline 5 minutes & 87.92 & 7.989 & 88.32 & 8.158 & 0.862 \\
\hline $\begin{array}{c}10 \\
\text { minutes }\end{array}$ & 85.00 & 8.670 & 87.52 & 7.66 & 0.282 \\
\hline $\begin{array}{c}15 \\
\text { minutes }\end{array}$ & 81.28 & 8.424 & 86.64 & 7.477 & 0.021 \\
\hline $\begin{array}{c}30 \\
\text { minutes } \\
\end{array}$ & 82.96 & 8.928 & 85.98 & 6.680 & 0.303 \\
\hline \begin{tabular}{c|c}
45 \\
minutes
\end{tabular} & 82.08 & 7.405 & 85.84 & 7.872 & 0.388 \\
\hline $\begin{array}{c}60 \\
\text { minutes }\end{array}$ & 81.44 & 7.269 & 85.60 & 7.681 & 0.055 \\
\hline & Cho & (1) & 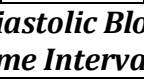 & $P$ & re at \\
\hline
\end{tabular}

The mean preoperative heart rate, respiratory rate, systolic blood pressure, diastolic blood pressure were similar in both groups ( $p$ value were $>0.05$ ). Likewise, the preinduction heart rate, respiratory rate, systolic blood pressure, diastolic blood pressure were recorded and they were similar in both groups.

There was no significant difference in systolic and diastolic blood pressure between two groups. After induction, there was a fall in the systolic and diastolic blood pressure in both the groups and there was no significant difference between the groups. Immediately after endotracheal intubation there was a significant increase in systolic and diastolic blood pressure in both groups and returned to the pre-induction value after 15 minutes.

Immediately before administration of midazolam the mean systolic and diastolic blood pressure were 121.52 and 82.28 in group I and 125.44 and 85.60 in group II which decreased to 111.12 and 73.80 in group I and 108.00 and 72.08 in group II respectively in the post-induction period. Following intubation, the systolic and diastolic blood pressure and heart rate rose to $142.00,94.68,114.16$ from pre-induction value of $121.52,82.28$ and 96.16 in group I while in group II it was 138.40, 92.40, 104.12 from 125.44, 85.60 and 94.32 respectively. The blood pressure and heart rate returned to the pre-induction values after 15 minutes of intubation in both groups and these changes were similar in both groups at 15 min., $30 \mathrm{~min} ., 45 \mathrm{~min}$., 1 hour, 2 hours in the post-operative period.

\begin{tabular}{|c|c|c|c|c|c|}
\hline $\begin{array}{c}\text { Sl. } \\
\text { No. }\end{array}$ & $\begin{array}{c}\text { Adverse } \\
\text { Effects }\end{array}$ & $\begin{array}{c}\text { Group-1 } \\
\text { (Number } \\
\text { of } \\
\text { Patients) }\end{array}$ & $\%$ & $\begin{array}{c}\text { Group-2 } \\
\text { (Number } \\
\text { of } \\
\text { Patients) }\end{array}$ & $\%$ \\
\hline 1 & Pain on injection & 0 & 0 & 0 & 0 \\
\hline 2 & Apnoea & 3 & 10 & 7 & 23.33 \\
\hline 3 & Allergic reaction & 0 & 0 & 0 & 0 \\
\hline 4 & Cough & 4 & 13.33 & 1 & 3.33 \\
\hline 5 & Hiccup & 0 & 0 & 0 & 0 \\
\hline 6 & $\begin{array}{c}\text { Tremor and } \\
\text { Twitching }\end{array}$ & 3 & 10 & 0 & 0 \\
\hline
\end{tabular}

\begin{tabular}{|c|c|c|c|c|c|}
\hline 7 & Hypertonus & 0 & 0 & 0 & 0 \\
\hline 8 & $\begin{array}{c}\text { Limb movements } \\
\text { during intubation }\end{array}$ & 8 & 26.67 & 1 & 3.33 \\
\hline 9 & Venous Sequelae & 0 & 0 & 0 & 0 \\
\hline 10 & $\begin{array}{c}\text { Post-operative } \\
\text { Respiratory } \\
\text { depression }\end{array}$ & 0 & 0 & 0 & 0 \\
\hline 11 & $\begin{array}{c}\text { Post-operative } \\
\text { Vomiting }\end{array}$ & 0 & 0 & 0 & 0 \\
\hline 12 & $\begin{array}{c}\text { Involuntary } \\
\text { movements }\end{array}$ & 2 & 6.67 & 0 & 0 \\
\hline Table 11. Comparison of Adverse Effect Between the 2 \\
Groups
\end{tabular}

Incidence of apnoea was more in group II, 7 patients out of 30 became apnoeic while in group I only 3 patients became apnoeic. None of the patients complained of pain during injection of the both groups; however, 4 patients in group I and 1 patient in group II had cough and in the group II 3 patients had tremor and twitching. In group I, 8 patients showed purposeful limb movements after administration of succinylcholine and in group II only 1 patient showed purposeful movements. Incidence of allergic rash, hiccup, hypertonus, venous sequelae, post-operative vomiting and respiratory depression were similar in both groups.

\section{Sedation Score by E.Wilson et al (1990)}

1. Awake and alert.

2. Awake but drowsy.

3. Eyes closed but arousable to command.

4. Eyes closed but arousable to mild physical stimulation.

5. Eyes closed but unarousable to mild physical stimulation.

\begin{tabular}{|c|c|c|}
\hline Sedation Score & $\begin{array}{c}\text { Group I } \\
(\mathbf{n = 3 0 )}\end{array}$ & $\begin{array}{c}\text { Group II } \\
(\mathbf{n = 3 0})\end{array}$ \\
\hline $1 . \quad$ Awake and alert & 7 & 5 \\
\hline $2 . \quad$ Awake but drowsy & 15 & 12 \\
\hline $3 . \quad \begin{array}{c}\text { Eyes closed but } \\
\text { arousable }\end{array}$ & 6 & 11 \\
\hline $4 . \quad \begin{array}{c}\text { Eyes closed but } \\
\text { arousable to mild } \\
\text { physical stimulation }\end{array}$ & 2 & 2 \\
\hline $\begin{array}{c}\text { 5. Eyes closed but } \\
\text { unarguable to mild } \\
\text { physical stimulation }\end{array}$ & 0 & 0 \\
\hline \multicolumn{2}{|c|}{ Table 12. Post-operative Sedation Score } \\
\hline
\end{tabular}

The recovery time following administration of reversal agents was 377.88 seconds in group I (range 296 seconds to 900 seconds) and 430.80 seconds in group II range (120 seconds to 900 seconds). Post-operative sedation was more in group II in comparison to group I. The average duration of anaesthesia and surgery were comparable in both the groups.

\section{DISCUSSION}

Induction involves the transition from an awake conscious state with intact productive reflexes to an unconscious state. Induction is accomplished when there is unresponsiveness to command and loss of eyelash reflexes. ${ }^{7}$ The present study is to find an effective dose of midazolam as an induction agent for induction of anaesthesia.

The ability of midazolam to induce sleep was slower in onset with wide interindividual variability ranging from 0.1 
$\mathrm{mg} / \mathrm{kg}$ to $0.4 \mathrm{mg}$ (JG Reves et al 1985$)^{3}$ in unpremedicated patients. The range of induction time following midazolam varies from 92 seconds to 140 seconds in group I with a mean induction time of 113.12 seconds and in group II with 80 seconds to 138 seconds with a mean induction time of 108.08 seconds showing a wide variation in response between individuals in both the groups. But with a dose of $0.2 \mathrm{mg} / \mathrm{kg}$ Jenson et al (1982) ${ }^{8}$ obtained a mean induction of 78 seconds. Reves and co-workers $(1978)^{3}$ obtained 73 seconds whereas Fragen, Gahl, and Caldwell (1978) ${ }^{9}$ using $0.15 \mathrm{mg} / \mathrm{kg}$ obtained value of 175 seconds, all in unpremedicated patients. D Al Khudairi ${ }^{10}$ in 1982 obtained a value of 30 seconds using 0.3 $\mathrm{mg} / \mathrm{kg}$ in premedicated patients.

In the study by Jenson et al, 8 besides midazolam, patients had received intravenous fentanyl at induction and it is likely that this could have potentiated the effects of midazolam. The above induction times are contrary to the results that were obtained in our study in both groups. Conner and his colleagues ${ }^{11}$ found a huge variation in response to midazolam. They also reported purposeful movements in patients anaesthetised with midazolam following administration of succinylcholine. This phenomenon was noted in the present study where 8 out of 30 patients (26.67\%) in group I and 1 out of 30 patients $(3.33 \%)$ in group II showed purposeful limb movements following administration of succinylcholine though they were adequately anaesthetised. Although this variability in response can be reduced by heavy premedication and increasing the dose of midazolam. This is only achieved at the cost of prolonging the recovery with more sedation postoperatively.

The Incidence of apnoea in group I was $10 \%$ and in group II was $23.33 \%$. This is comparable with the studies conducted by Fragen, Gahl, and Caldwell ${ }^{9}$ in 1978 and also J Kanto et al ${ }^{12}$ in 1982 but Jenson \& colleagues (1982) ${ }^{8}$ observed $77 \%$ of apnoea with midazolam $0.2 \mathrm{mg} / \mathrm{kg}$ and premedication with morphine $0.1 \mathrm{mg} / \mathrm{kg}$ and scopolamine $8 \mathrm{mg} / \mathrm{kg}$. In the present study, the baseline cardiovascular indices were similar in both groups. The pre-induction value of systolic blood pressure, diastolic blood pressure and pulse rate in group I were 121.52, 82.28 and 96.16 and in group II were $125.44,85.60$ and 94.32 ; and the post-induction values in group I were 111.12, 73.80 and 88.88 and group II were 108.00, 72.08 and 86.16 respectively which was similar to the studies by John Abraham and B. Kaur (1997) ${ }^{7}$ but contrary to the results obtained from the study by Jenson ${ }^{8}$ in 1982, Fragen and co-workers ${ }^{9}$ in 1978 and J Kanto et al ${ }^{12}$ in 1982 who reported no significant difference in systolic pressure, diastolic pressure and heart rate. There was a marginal fall in the pulse rate at the postinduction period and was similar to the report by John Abraham and B Kaur (1997). ${ }^{7}$

Following intubation, the changes in systolic blood pressure, diastolic blood pressure and heart rate were similar in both groups indicating that increasing the dose of midazolam dose not attenuate the haemodynamic response to laryngoscope and endotracheal intubation. ${ }^{13}$ This was confirmatory to the study by Lopez et al (1991)14 that midazolam does not attenuate the cardiovascular response to intubation. Likewise changes in the systolic blood pressure, diastolic blood pressure and heart rate were similar during intraoperative period and the haemodynamic changes following intubation returned to the pre-induction values within $10-20$ minutes. ${ }^{15}$ The incidence of cough was $13.33 \%$ in group I and $3.33 \%$ in group II. None of the patients complained of pain on injection in both the groups and similarly there is no incidence of allergic rashes, hiccup, hypertonus, venous sequelae, postoperative vomiting and respiratory depression in both the groups. The recovery from anaesthesia was significantly more in group II (430.80 seconds) than group I (377.88 seconds) and the incidence of postoperative sedation was more in the group II than group I patients and this is probably due to increase in dosage. But the recovery time was significantly shorter in patients undergoing major surgical procedures where the duration of surgery was more than two hours.

\section{CONCLUSION}

This study showed that midazolam in a dose of $0.3 \mathrm{mg} / \mathrm{kg}$ was more ideal to induce clinical acceptable anaesthesia since induction and recovery were smooth and pleasant, with a stable cardiovascular system and less incidence of apnoea. Sedative effect lasted longer, thus decreasing the amount of analgesic need following surgery. There was no untoward complication. Hence, midazolam can be used as an induction agent in patients undergoing major surgical procedures.

\section{REFERENCES}

[1] Forster A, Gardaz JP, Suter PM, et al. I.V. midazolam as an induction agent for anaesthesia: a study in volunteers. British Journal of Anaesthesia 1980;52(9):907-11.

[2] Lundy JS. Balanced anesthesia. Minn Med 1926;9(399):e404.

[3] Reves JG, Fragen RJ, Vinik HR, et al. Midazolam: pharmacology and uses. Anaesthesiology 1985;62(3):310-24.

[4] Gamble JA, Kawar P, Dundee JW, et al. Evaluation of midazolam as an intravenous induction agent. Anaesthesia 1981;36(9):868-73.

[5] Izuora KL. Midazolam in emergency surgery -pilot study on adult Nigerian patients. West African Journal of Medicine 1994;13(2):70-2.

[6] Gross JB, Zebrowski ME, Carel WD, et al. The course of ventilator depression after thiopentone sodium and midazolam in normal patients and in patients with chronic obstructive pulmonary disease. Anaesthesiology 1983;58(6):540-4.

[7] Abraham J, Kaur B. Evaluation of midazolam as an intravenous induction agent for general anaesthesiacomparison with thiopentone. Indian Journal of Anaesthesia 1997;41(5):34-7.

[8] Jensen S, Schou-Olesen A, Huttel MS. Use of midazolam as an induction agent: comparison with thiopentone. British Journal of Anaesthesiology 1982;54(6):605-7.

[9] Fragen RJ, Gahi F, Caldwell N. A water-soluble benzodiazepine, R021-3981, for induction of anesthesia. Anesthesiology 1978;49(1):41-3.

[10] AL-Khudhari D, Whitwam JG, Chakrabarti MK, et al. Haemodynamic effects of midazolam and thiopentone during induction of anaesthesia for coronary artery surgery. British Journal Anaesthesia 1982;54(8):831-5.

[11] Conner JT, Katz RL, Pagano RR, et al. Ro 21-3981 for Intravenous surgical premedication and induction of Anaesthesia. Anaesthesia Analgesia 1978;57(1):1-5. 
[12] Kanto J, Sjavoll S, Vuori A. Effect of different kinds of premedication on the induction properties of midazolam. British Journal of Anaesthesia 1982;54(5):507-11.

[13] Jones RD, Visram AR, Chan MM, et al. A comparison of three induction agents in paediatric anaesthesiacardiovascular effects and recovery. Anaesthesia of Intensive Care 1994;22(5):545-55.
[14] López SF, Rivas LFA, Crespo JT, et al. Cardiovascular response to orotracheal intubation using midazolam or etomidate in anaesthesia induction. Rev Esp Anestesiol Reanim 1991;38(3):170-2.

[15] Samuelson PN, Reves JG, Kouchoukos NT, et al. Haemodynamic responses to anaesthetic induction with midazolam or diazepam in patients with ischemic heart disease. Anaesthesia Analgesia 1981;60(11): 802-9. 